THIS PAGE INTENTIONALLY LEFT BLANK 


\title{
HERALDRY FOR THE DEAD
}

\author{
Memory, Identity, and the \\ Engraved Stone Plaques of Neolithic Iberia
}

KATINA T. LILLIOS

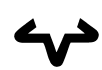

UNIVERSITY OF TEXAS PRESS

Austin 
This book has been supported by an endowment dedicated to classics and the ancient world and funded by the Areté Foundation; the Gladys Krieble Delmas Foundation; the Dougherty Foundation; the James R. Dougherty, Jr. Foundation; the Rachael and Ben Vaughan Foundation; and the National Endowment for the Humanities. The endowment has also benefited from gifts by Mark and Jo Ann Finley, Lucy Shoe Meritt, the late Anne Byrd Nalle, and other individual donors.

Copyright (C) 2008 by the University of Texas Press

All rights reserved

Printed in the United States of America

First edition, 2008

Requests for permission to reproduce material from this work should be sent to:

Permissions

University of Texas Press

P.O. Box 7819

Austin, TX 78713-7819

www.utexas.edu/utpress/about/bpermission.html

(2) The paper used in this book meets the minimum requirements of ANSI/NISO Z39.48-1992 (RI997) (Permanence of Paper).

Library of Congress Cataloging-in-Publication Data

Lillios, Katina T., 1960-

Heraldry for the dead : memory, identity, and the engraved stone plaques of neolithic Iberia / Katina T. Lillios. — 1st ed.

$$
\text { p. cm. }
$$

Includes bibliographical references and index. ISBN 978-0-292-71822-7 (cloth : alk. paper)

1. Neolithic period-Iberian Peninsula. 2. Plaques, plaquettes—Iberian Peninsula. 3. Burial-Iberian Peninsula. 4. Antiquities, Prehistoric-Iberian Peninsula.

5. Iberian Peninsula—Antiquities. I. Title.

$$
\begin{gathered}
\text { GN776.22.I34L55 } 2008 \\
\text { 936.6-dc22 } \\
2008017086
\end{gathered}
$$


For Morten, who nourished, for Rasmus, who clarified, and for my father, who accepted. And for my mother, who did not live to see its completion, but who believed. 
THIS PAGE INTENTIONALLY LEFT BLANK 